Dmytro V. Stefanyshyn ${ }^{1}$, Doctor of Science (Eng.), Lead researcher of the Institute of Telecommunications and Global Information Space of the NASU, Professor of Department of Hydrotechnical Construction and hydraulic of National University of Water and Environmental Engineering (NUWEE)

ORCID ID: 0000-0002-7620-1613 e-mail:d.v.stefanyshyn@nuwm.edu.ua

Vasyl M. Korbutiak ${ }^{1}, \mathrm{PhD}$ in Technical Sciences, associate professor of Department of Land Management, Cadastre, Land Monitoring and Geoinformatics

ORCID ID: 0000-0002-8273-2306

Yulija D. Stefanyshyna-Gavryliuk ${ }^{2}$, Master in Ecology and Environmental Protection, Manager of PP "AM Lingvista"

ORCID ID: 0000-0002-4121-5484

${ }^{1}$ National University of Water and Environmental Engineering (NUWEE), Rivne, Ukraine ${ }^{2} \mathrm{PP}$ “AM Lingvista”, Rivne, Ukraine

\title{
SITUATIONAL PREDICTIVE MODELLING OF THE FLOOD HAZARD IN THE DNIESTER RIVER VALLEY NEAR THE TOWN OF HALYCH
}

\begin{abstract}
There has been presented a method of situational predictive modelling of the flood hazard in the Dniester River valley near the town of Halych based of hydrological observations data obtained at the Halych water level gauge. Some features in the behaviour of the equation of relationship between levels and water discharges for the Halych water level gauge were revealed, in particularly, regularities fostering reliable forecasting the flood hazard by means of statistical data and ambiguities interfering similar predicting. The possibility of effective situational predicting of the flood hazard according to current data of hydrological observations to minimize probable harm and losses was shown.
\end{abstract}

Keywords: ambiguity; data; the Dniester River; flood hazard; hydrological observations; situational model; situational predictive modelling

\section{Introduction}

Floods on rivers are being considered among the most dangerous natural disasters causing different losses including human fatalities [1]. By the number of human victims, they yield only to catastrophic earthquakes. In the 20th century [2], floods of different genesis were responsible for about 6.8 million deaths. Majority of these victims were concerned to floods on rivers.

At present, annual economic worldwide losses from floods have already reached hundreds of millions of dollars [3] and have tendency to grow in the future. This is happening despite the growing human capabilities to withstand the environment. The valleys of rivers and riparian zones have traditionally been considered by human as an important environment resource to use in the economic activity. These areas were, are and will stay the centres of urbanization and mass settlement of people. This is explained not only by the increase of the general deficit of land resources in the world, in particular, because of the decrease of soil fertility on a considerable part of the globe, or the increase of erosion processes of different etymology, etc. [4]. In

(C) D.V. Stefanyshyn, V.M. Korbutiak, Y.D. Stefanyshyna-Gavryliuk, 2019 
addition to significant water and land resources, these territories have got hydroelectric resources, fishery, forest, recreational, cultural-historical and aesthetic resources, etc. But, undoubtedly, the most valuable natural element of contiguous riparian territories is the unique combination of water and land resources. Therefore, regardless the essential risk of harm, deaths and losses due to floods on rivers increasing by years, humans keep on using contiguous riparian territories for their life activity [5].

One of the most known contiguous riparian zone among such areas on Ukrainian territory is the Upper Dniester Basin [6-8], and, in particularly, the Dniester floodplain near the town of Halych.

This territory belongs to the Carpathian Mountainous Part of the Dniester Basin. It largely occupies the upper right-bank area of the river catchment, featuring a welldeveloped and dense hydrographic network (comprising the Strviazh, Vereschytsia, Striy, Svicha, Limnytsia, Lukva and many other tributaries) that provides a major proportion of flow to the Dniester. Despite the fact that the Carpathian Mountains (including foothills) occupy less than $9 \%$ of the Basin area, and the upper (Carpathian) Dniester tributaries drain only about 17\% of the river catchment, over $50 \%$ of the Dniester flow is collected in this part [7].

The town of Halych is placed in the lake-shaped extended valley of the Dniester River where upstream and downstream the mouths of those tributaries are located. During floods on the Dniester River, there, probably, the largest mass of water accumulates, sometimes with rising water levels up to 10-12 meters, causing catastrophic consequences (Fig. 1, 2).

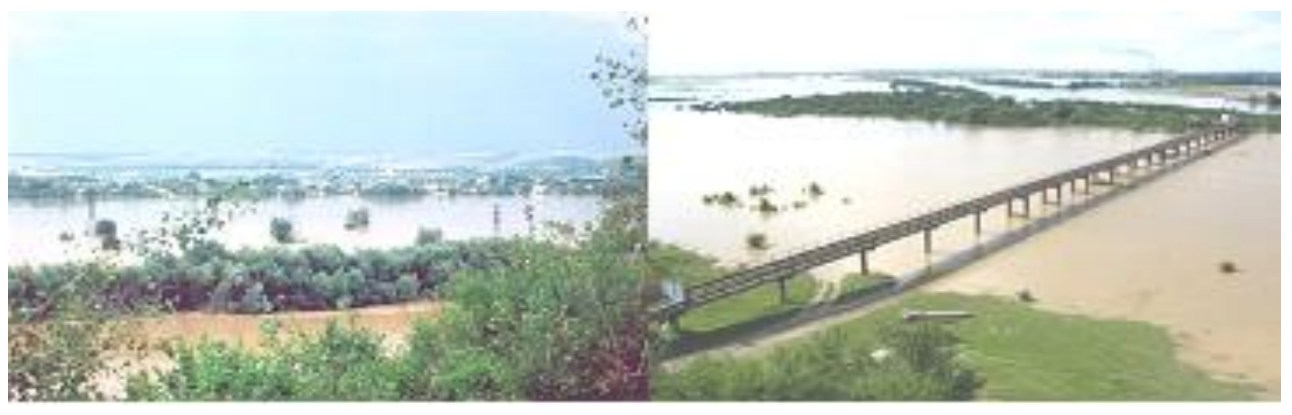

Fig. 1 - The Dniester River during the flood on July 26-28, 2008, in the upstream stretches of the river near the town of Halych (http://valentyn.io.ua/album163445)

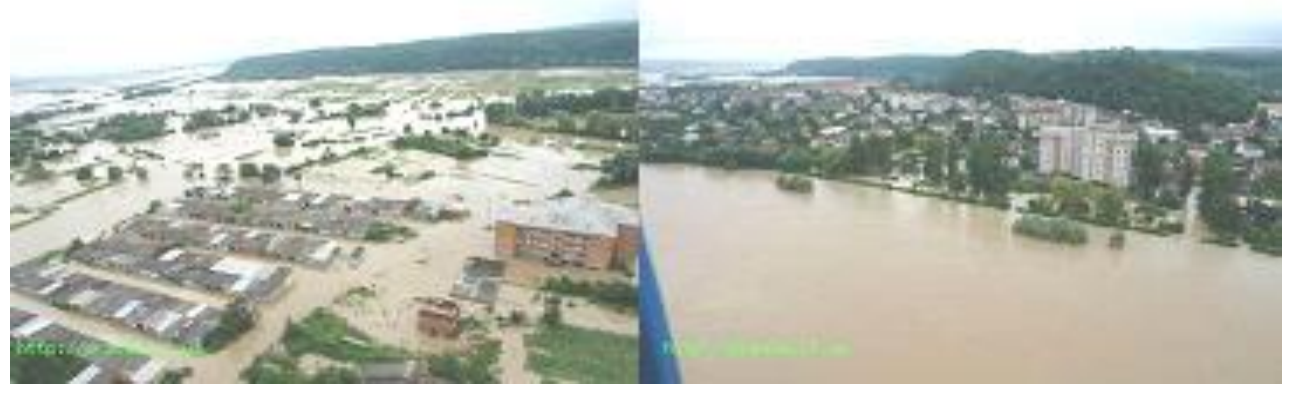

Fig. 2 - The flooding the town of Halych during the flood on July 26-28, 2008, on the Dniester River (http://pravda.if.ua/news-4004.html) 
Generally, the modeling of the flood hazard in the Dniester River valley near the town of Halych is a challenging problem bearing important meaning not only to local population (See Fig. 2). A number of critical infrastructure objects are located at this area, such as bridges of nation-wide importance, etc., as well as Burshtynska thermal power station (See Fig. 1, in the right upper corner).

\section{Common remarks concerning to situational and predictive modelling}

\subsection{Situational modelling}

Situational modelling is usually undertaken to understanding and restoration of certain situations (the coincidence of the conditions and circumstances of the functionality) relating to behaviour of complex systems [9-13].

Situational modelling has become especially popular in economics, medicine, military affairs, forensics, politics, and other similar spheres, as well as in artificial intelligence, where the development of a logical approach to modelling the behaviour of complex systems and processes gave impetus to the creation of situational calculus theory [9-11].

The basic idea of situational modelling is that a complete description of the infinite set of all possible situations of the functioning of a real system is replaced by a certain finite set of generalized situations that reproduce to a certain degree the system's possible states [9-13]. The evolution of the dynamic system is modelled in the context of its "movement" along a series of situations that are the result of various actions. These different model situations (by R. Reiter [10]) do not determine literally appropriate states of the system; they show only the history of certain events as completed sequences of actions in certain periods of time.

Since situations cannot be described totally, and it is possible to speak only about some of their aspects, the non monotonic output rule is used to describe the evolution of the system. In modelling, it is assumed (by J. McCarthy [11]) that on the basis of past facts, by which past situations are described, and on using some general rules or assumptions, according to which execution of actions and occurrence of events within situations take place, it is possible to predict some similar situations that will appear in the future.

In this study, the definitions "a situational model", "situational modelling" are related to a predictive model or predictive modelling adapted to some separate situation, which unfolds in time, in order to simplify modelling based on monitoring data and increase its adequacy and accuracy $[12,13]$. On predictive modelling, the circumstances of this adaptation are named like a predictive background and it is admitted that situational models constructed with using corresponding time series can reflect various phase states of a dynamic system at different time intervals.

\subsection{Predictive modelling}

Predictive modelling uses statistics to predict outcomes [14-17]. So, for example, a popular and well-known predictive mathematical model in hydrology based on statistics (on hydrological observations data) is the probability distribution function [18-21]. This model can be used to determine flood parameters and its occurrence probability if corresponding time series of hydrological observations data are 
uninterrupted and stationary, that is, they form representative sequences of independent and identically distributed random variables.

The other popular predictive models based on monitoring data and used for predicting natural and technogenous phenomena and processes are the regression ones [14]. Now, there are many modern regression models are highly adaptable; they are capable of modeling complex relationships [14, 15]. Regarding hydrological phenomena, the typical regression model there is an equation of relation between water discharges and water levels.

The use of regression models enables to simplify significantly problems of modeling and predicting based on experimental data, giving the possibility making decisions in various challenging situations avoiding the use more complex phenomenological models, for instance, such like equations of the mathematical physics, etc. However, classic regression models built with using time series can be the most successful in case of data interpretation and interpolation, but not to predict outcomes. In predicting they can get lost their accuracy and attractiveness. This is especially true of multiple regression models. Often, complex regression models very easily overemphasize patterns that are not reproducible and demonstrate instability of extrapolation in prediction zone. So a researcher cannot know about the fatal prediction faults until the next set of samples appears.

Nevertheless, admittedly, the regression models are the most convenient models to solve practical prediction problems in various fields. They can be formalized and adapted relatively easy, especially for short time series meeting certain established homogeneity criteria [16, 17]. Also they may be modified in appropriate way depending on peculiarities of prediction tasks $[12,13]$.

\subsection{Some additional remarks concerning predictive modelling}

Practice shows, the construction of adequate regression models for predictive purposes can be a challenging problem, even in simple cases [12-14]. Often, better interpretation models may have a tendency to overpredict (or underpredict) low values and underpredict (or overpredict) high ones [14].

Perhaps, the problem is that regression models are traditionally built as models that should suit the best way all collected data (following the principle of optimization). So, the increase of the number of observation data may complicate execution of important limit restrictions of regression modelling [12, 13].

That is, if we make structure of regression model more difficult in any way, for example, by taking into account additional factors, parameters, and nonlinear effects, etc., the quality of regression models as interpretative models for observed data can be improved. But their quality as predictive models may be deteriorated. If there is more than one predictor, a researcher will have to further understand characteristics of different predictors and the relationships among them. Between-predictor correlations may be a serious problem. It is well known, the simplest way to solve the multicollinearity problem is to remove the predictors that have the most correlated relationships. Usually, if predictors are highly intercorrelated, this implies that they are measuring the same underlying information. Removing some of them might lead to a more parsimonious and interpretable model without compromising the performance of the model [12-17].

There are also other potential advantages of removing predictors prior to modelling. First, fewer predictors will decrease computational time and complexity. 
Second, some models can be improved significantly in model performance and/or their stability will increase without the problematic variables. But all these simplifications should be justified in terms of predicting. It should also be mentioned that the main idea of regression modelling, as it is well known, is that regression occurs when a dependent, endogenous variable depends not only on some independent, exogenous, explanatory variables (predictors), as well on some uncontrolled, unknown factors.

\section{Input data and the main objective of the researches}

As input data on the modelling, available to us time series of hydrological observations data for water discharges and water levels maxima of the Dniester River, the Halych water level gauge, were used. Those were incomplete time series, with data from 1895 to 1998 (See Fig. 3, 4). Further, all numerical calculations and simulations were carried out according to the data given in Fig. 3, 4. In general, that was a retrospective simulation in condition of incompleteness of data and their ambiguity, that a bit complicated our task.

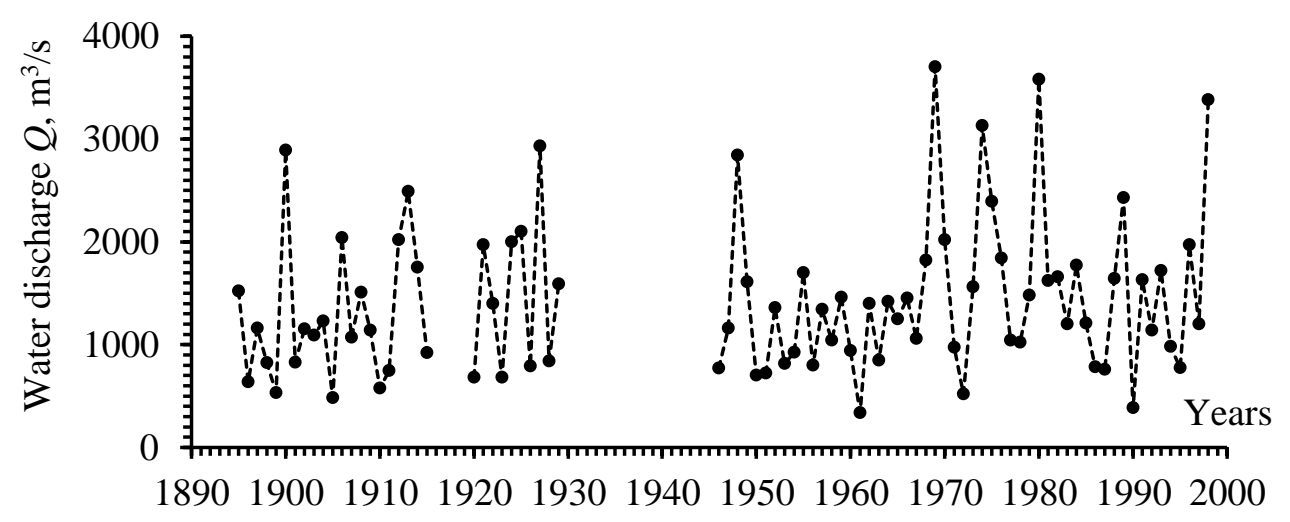

Fig. 3 - The time series of water discharges maxima (the Dniester River, the Halych water level gauge)

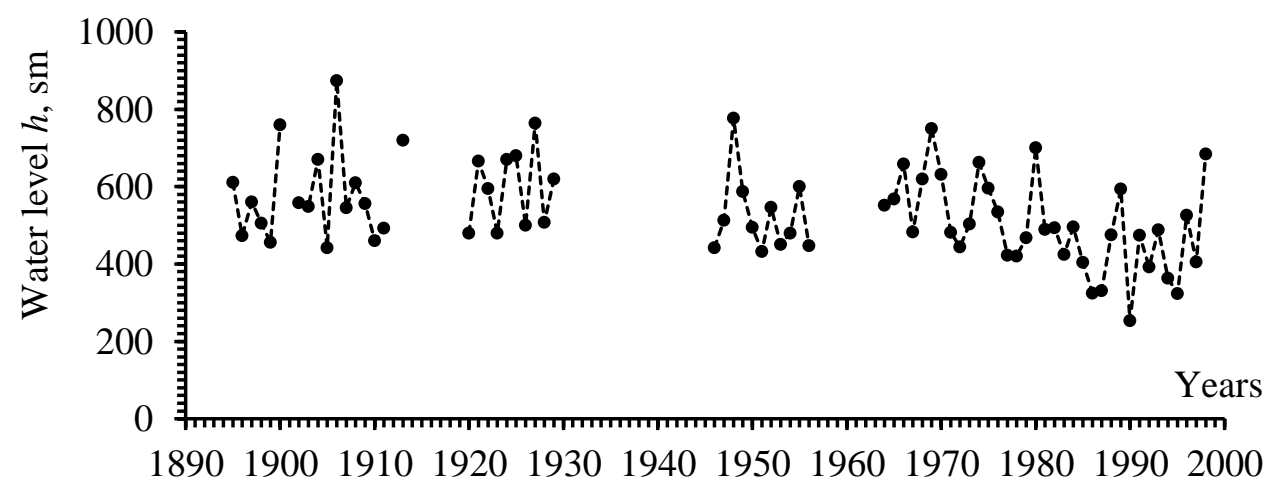

Fig. 4 - The time series of water levels maxima (the Dniester River, the Halych water level gauge) 
The main objective of these researches was the available data analysis with developing and presentation a practice way to predict the flood hazard in the Dniester River valley near the town of Halych on base of hydrological observations data, in particular, taking into account their incompleteness and ambiguity.

\section{Preliminary researches to predicting the flood hazard}

The best indicator for quantifying the flood hazard in-situ is the forecasted water level in the river. Depending on the expected level of water in the river during future flood, areas to be flooded may be identified and mapped as easy as possible.

The challenge is that forecasting the water levels in rivers is a difficult task even in the case of representative series of observations data. Typically, the time series generated by observations of water levels in the rivers are non-stationary ones (See, above, Fig. 4). In addition to the fact that water levels in rivers depend on water discharges, they may depend on the hydromorphology of a river bed and its floodplain, and other factors that may be not only stochastic, but and unpredictable ones, both natural and anthropogenic. For example, in some parts of rivers, the essential local elevations of water levels may occur due to compressions of their channels downstream due to ice gorges, rubbish of logging etc.

At the same time, if time series of maximum water discharges are stationary or quasi-stationary, the model of independent and identically distributed random variable may be used to predict them. For most rivers that have not undergone significant anthropogenic loads and in the presence of data of continuous hydrological observations within time intervals of at least 30-40 years, this assumption can be quite admitted [18-20].

This model allows relatively simply predicting water discharges with low annual probability of exceedance $P, \%$, namely the discharges causing high water levels. In Fig. 5 there are three alternative probability distributions that can be used to forecast water discharges on the Dniester River, the Halych water level gauge, of various probabilities: the model 1 is the type I Gumbel distribution; the models 2 and 3 are the three-parameter gamma distribution (the Krytsky-Menkel model), with $C_{V}=0,5$ and $C_{S}=2 C_{V}$, and with $C_{V}=0,6$ and $C_{S}=2 C_{V}$, respectively, where $C_{V}$ is the coefficient of variation, $C_{S}$ is the coefficient of asymmetry.

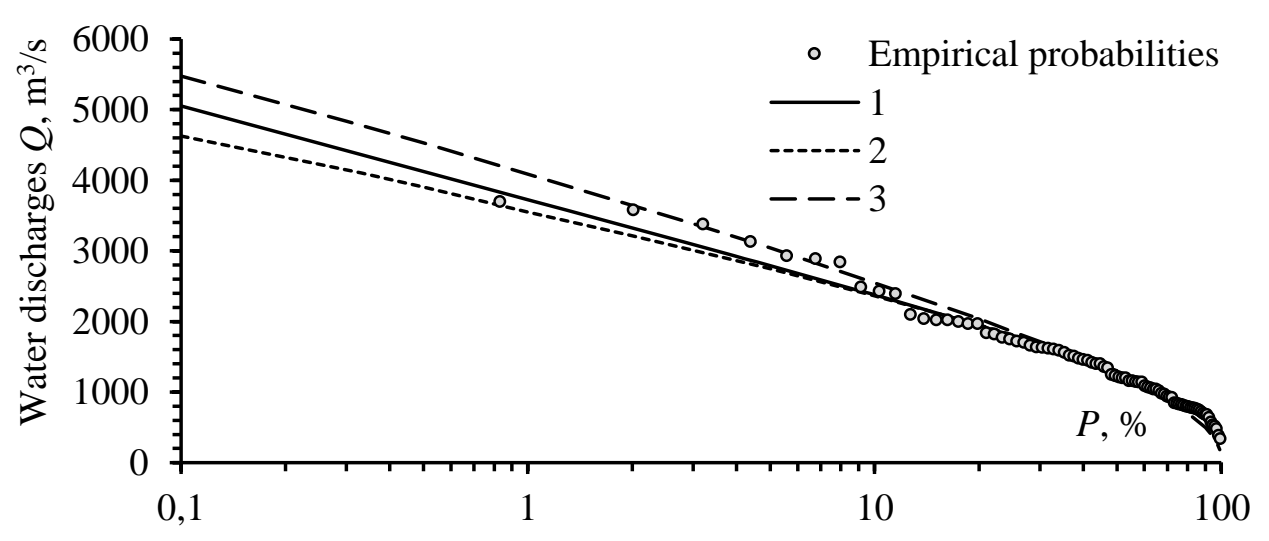

Fig. 5 - Examples of water discharges maxima probability distributions (were built according to data given in Fig. 3) 
It should be noted, the model presented as a function of probability distribution can be used to determine the discharge with the appropriate probability of occurrence, or the probability of the corresponding water discharge. In the next step, an equation of relationship between levels and water discharges may be used to predict corresponding water levels to map zones of flooding.

The equation of relationship between levels and water discharges $h=f(Q)$, where $h$ is the predicted water level and $Q$ is the expected water discharge given probability of exceedance $P, \%$, is a well-known and quite often used hydrological and hydraulic model (Fig. 6). This is a convenient model to use in practice, but it should be borne in mind the equation of relationship between levels and water discharges can highly change over time (Fig. 7), and, accordingly, the model should constantly adjust to new data.

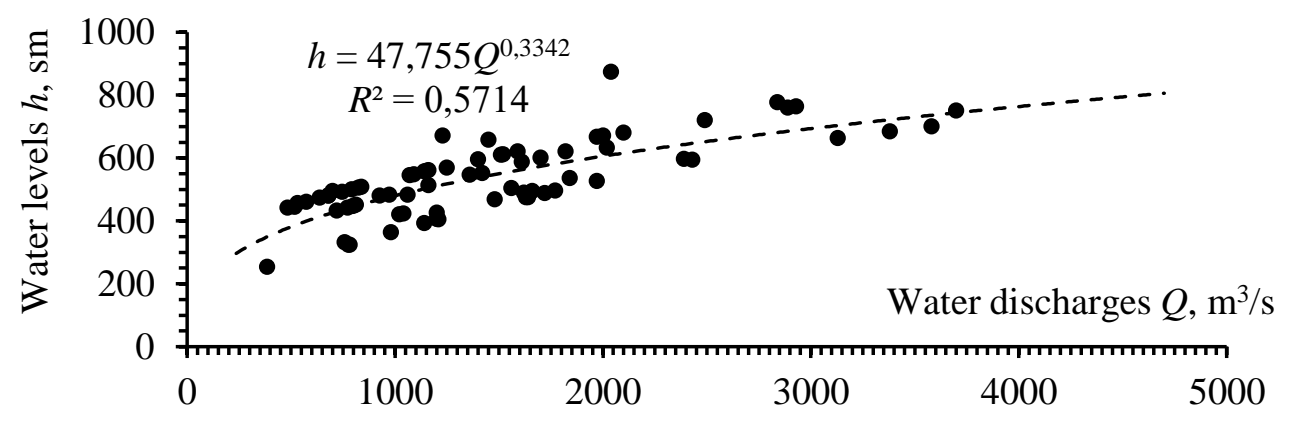

Fig. 6 - A generalised equation of relationship between levels and water discharges (was built according to data given in Fig. 3, 4)

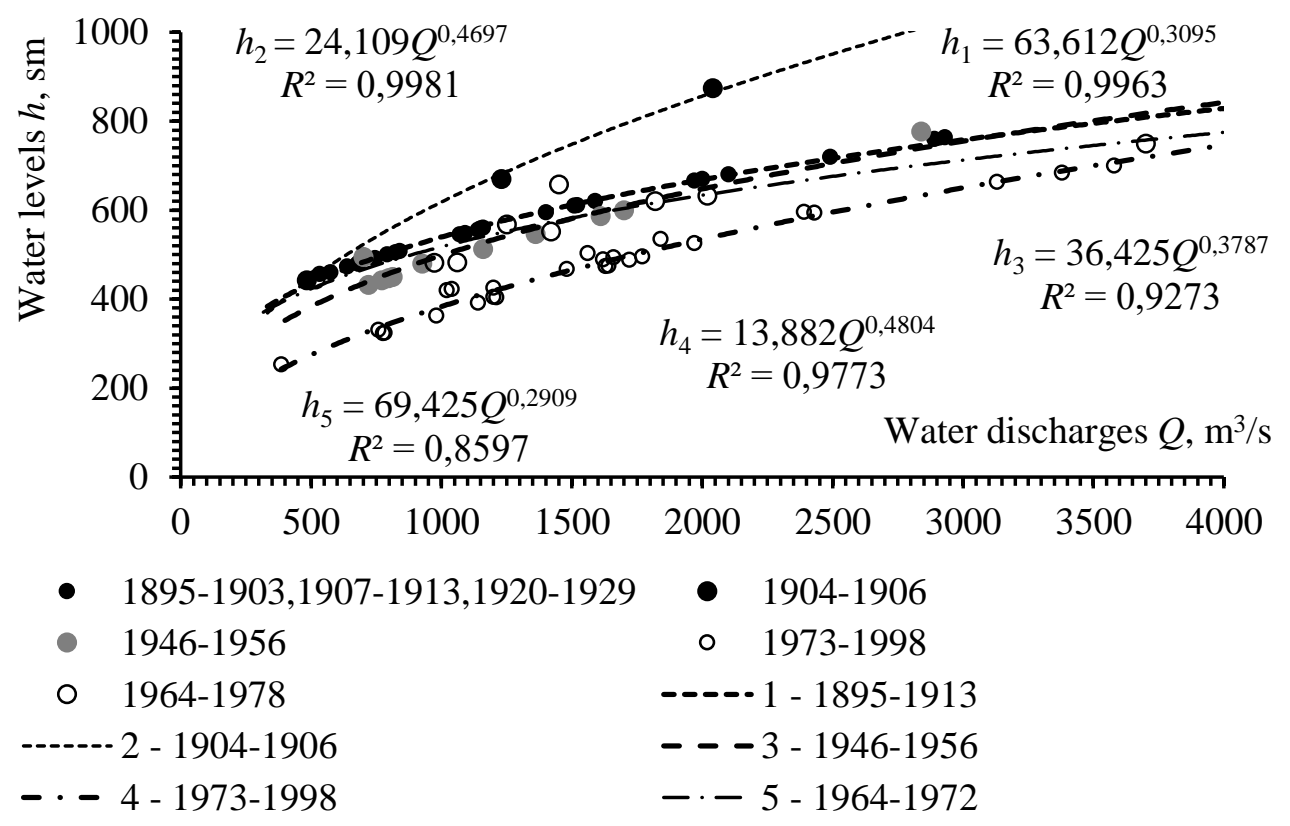

Fig. 7 - A set of equations of relationship between levels and water discharges (the Dniester River, the Halych water level gauge) 
In how much, depending on different situations described by appropriate equations of relationship between levels and water discharges, the flooded plots may vary, even if practically the same values of water discharges happen, shown is in Fig. 8. So, in 1906, when the water discharge maximum was $2040 \mathrm{~m}^{3} / \mathrm{s}$, the water level reached $874 \mathrm{sm}$; in 1970, when the water discharge maximum was $2020 \mathrm{~m}^{3} / \mathrm{s}$, the water level was $632 \mathrm{sm}$.

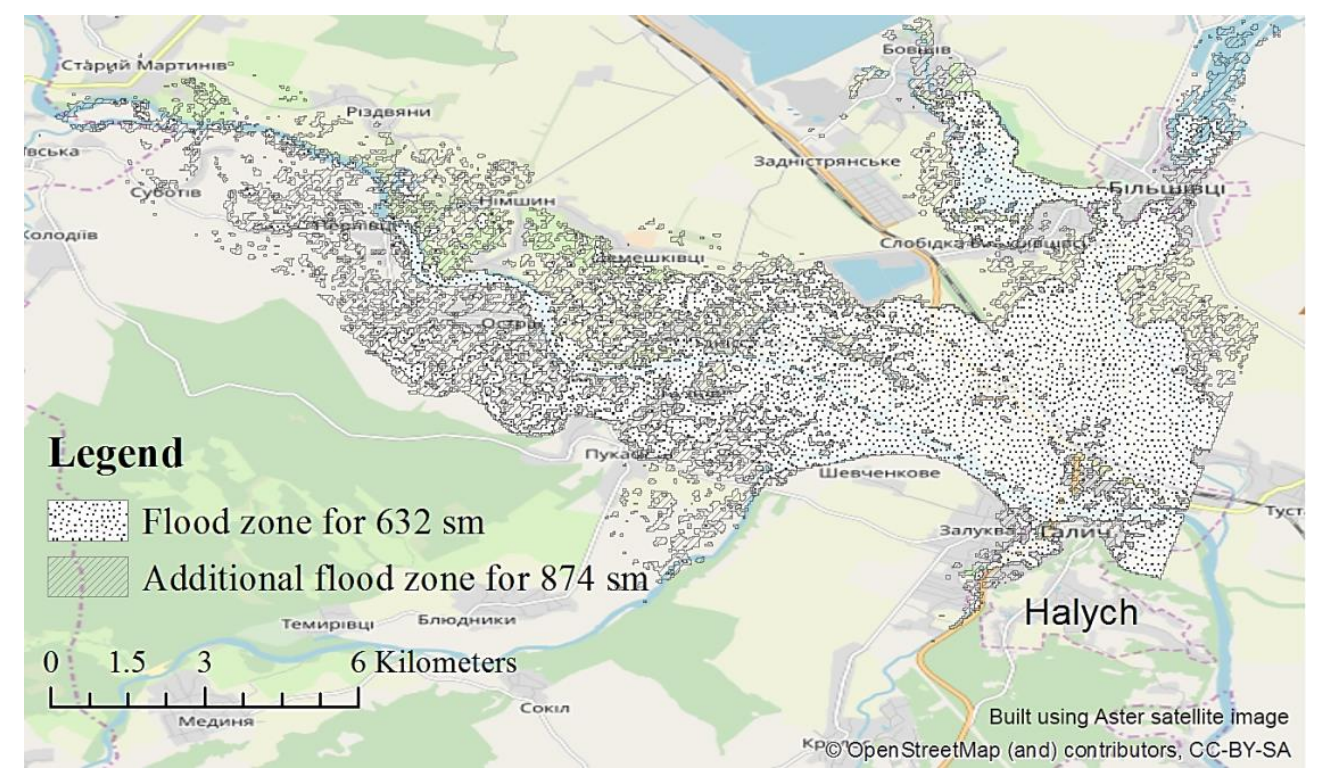

Fig. 8 - Flooded plots modelling in the Dniester River valley near the town of Halych (according to data the Halych water level gauge)

This adjusting to new data (See Fig. 7), which allows us to provide the required quality and accuracy of the equation of relationship between levels and water discharges, may be called the situational modelling of the flood hazard in-situ. In this case, an appropriate situational model is not only a quite simple single-factor regression model presenting dependence of a dependent variable $h$ on one independent predictor $Q$. Essentially, this is an empirical model $h=a Q^{b}$ that may be used as a formula to predicting flood hazards for the next floods if the predictive background expected unchangeable and the water discharge of the corresponding probability of exceedance $P, \%$, has been known (See, Fig. 5).

\section{Some advanced results and conclusions concerning situational modelling of the flood hazard in the Dniester River valley near the town of Halych}

The basic assumption in situational modelling is the assumption that a predictive background will be unchangeable in time $[12,13]$. In fact, constancy of a predictive background determines the only specific situation for which the relevant situational model can be considered adequate.

In general, a predictive background can be considered as a set of external and (or) internal conditions including unknown predictors that can be essential for the choice of the structure of the relevant situational model or values of its coefficients. Obviously, these conditions can be constantly changing in time. Changes can be both 
regular and irregular, both stochastic (probabilistic) and unpredictable, uncertain or ambiguous. Some of these changes are actually impossible to predict and estimate. If regular changes can be taken into account when introducing some additional variables into the model, it is practically impossible, for example, to do this for irregular changes. In this case, the comparing this situation with the famous "black swan" by Nassim Taleb [22] comes to mind.

It is reasonable to assume that the smaller duration of the model situation in time is, the more likely the constancy of the relevant predictive background we can expect. It is only important that the appropriate time series representativeness was ensured within the selected time interval [13, 23, 24].

In Fig. 9, 10, shown are sets of such retrospective situational models built according to data given in Fig. 3, 4.

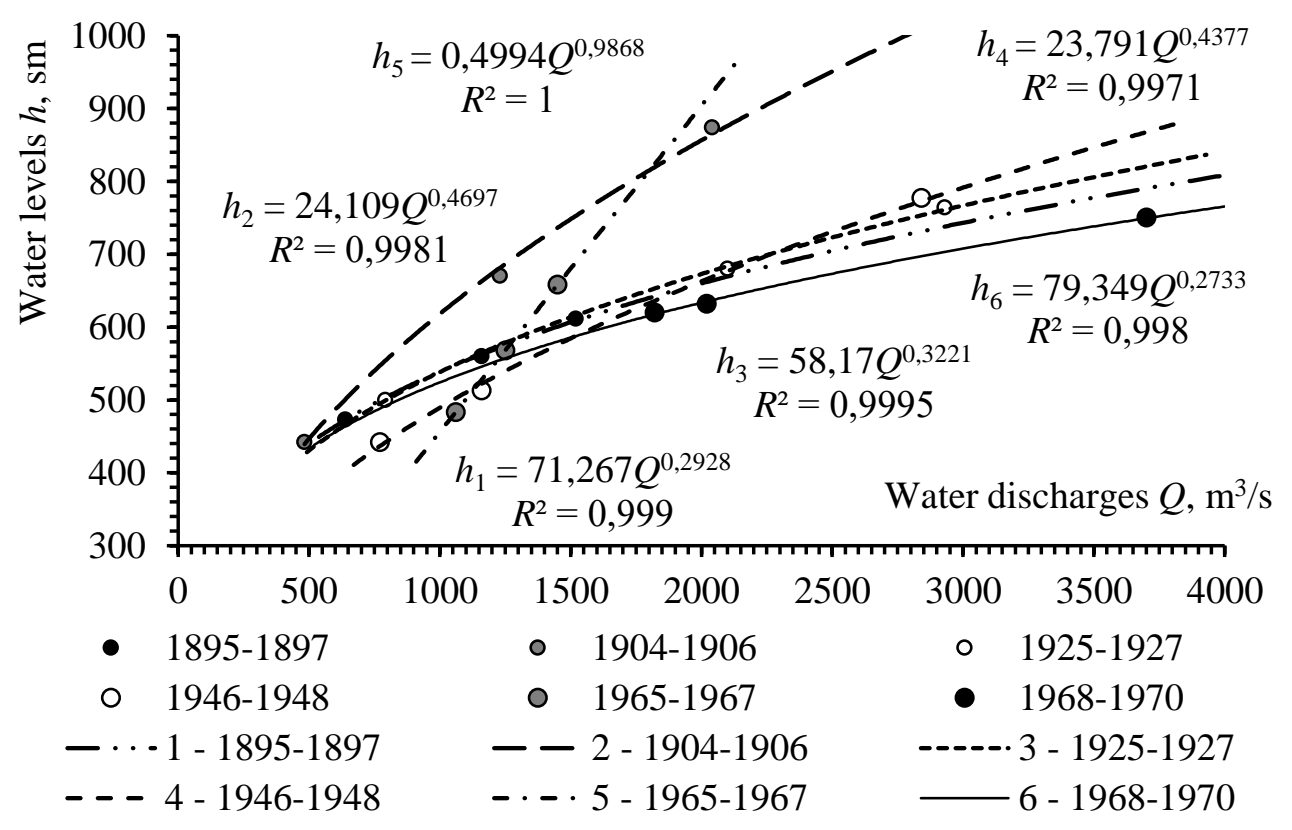

Fig. 9 - A set of retrospective situational models to predict the flood hazard in the Dniester River valley near the town of Halych (models were built according to data from 1895 to 1970, See Fig. 3, 4)

As for the duration of predictive backgrounds to provide reliable situational modelling, as an important result of our research got was the following. It was revealed that for the Dniester River, at Halych water level gauge, the limit duration of the unchangeable predictive background to build the still dependable situational predictive model to forecast of the flood hazard in the Dniester River valley near the town of Halych is within three years. And a fairly reliable model $h=a Q^{b}$, which can be used as an appropriate situational model to predict the flood hazard in-situ, can be obtained in case of three corresponding values of water levels and water discharges exceeding 500-1000 m³/s (See Fig. 9, 10). 


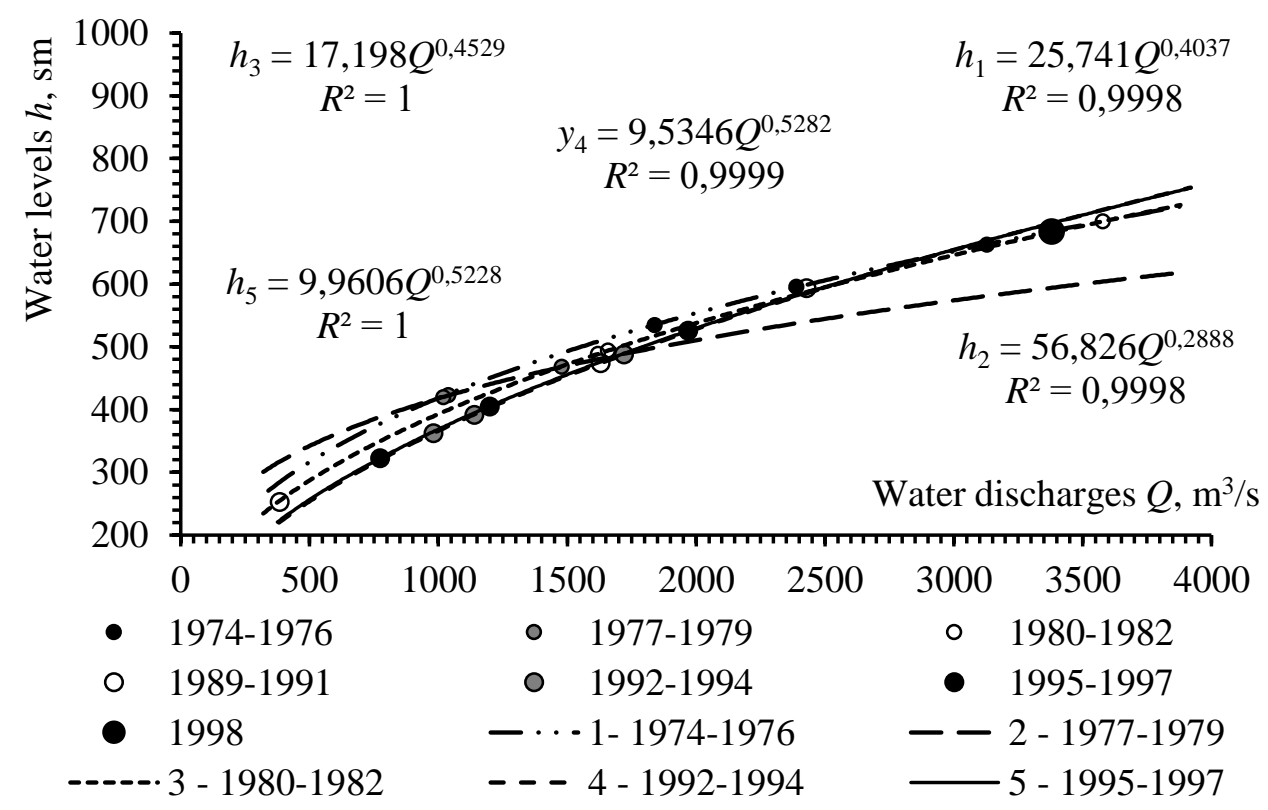

Fig. 10 - A set of retrospective situational models to predict the flood hazard in the Dniester River valley near the town of Halych (models were built according to data from 1974 to 1997, See Fig. 3, 4)

In Fig. 10, as an example, shown is the point corresponding to the 1998 data. This point already has a deviation from the nearest situational model 5. Although the difference between the predicted value of water level according to model 5 and the observed value of the water level is only $13 \mathrm{~cm}$, it can be essential when the situational predicting is carried out taking into account the characteristics of the river valley transverse profile in a particular plot. In addition, among situational models in Fig. 9, 10 there are three models that can be called "black swans" (See the models 2 and 5 in Fig. 9 and the model 2 in Fig. 10). The existence of these models convinces us that the predictive background for situational modelling the flood hazard in the Dniester River valley near the town of Halych should be limited to three years to avoid gross mistakes.

\section{REFERENCES}

1. Abbott, P. L. (1996). Natural Disasters. Wm. C. Brown Publishing Co.

2. Doocy, S., Daniels, A., Murray, S., \& Kirsch, T. D. (2013). The Human Impact of Floods: A Historical Review of Events 1980-2009 and Systematic Literature Review. PLoS Currents. doi:10.1371/currents.dis.f4deb457904936b07c09daa98ee8171a

3. Dobrovičová, S., Dobrovič, R., \& Dobrovič, J. (2015). The Economic impact of floods and their importance in different Regions of the World with Emphasis on Europe. In Business Economics and Management 2015 Conference, BEM2015 (pp. 649-655).

4. Kundzewicz, Z. W., Ulbrich, U. et al. (2005). Summer Floods in Central Europe Climate Change Track? Natural Hazards, 36(1-2), 165-189.

5. Rufat, S., Tate, E., Burton, Ch. G., \& Maroof, A. Say. (2015). Social vulnerability to floods: Review of case studies and implications for measurement. International Journal of Disaster Risk Reduction, (14), 470-486. 
6. Shulyarenko, A., Yatsyuk, M., \& Shularenko, I. (n.d.). Causes and peculiarities of recent floods on the Dniester River (J. Marsalek, Ed.). In Flood Issues in Contemporary Water Management (Vol. 71, NATO Science Series 2. Environmental Security, pp. 95-100).

7. OSCE/UNECE Project. (2005). Transboundary diagnostic study for the Dniester River basin. Retrieved from https://www.osce.org/ukraine/104057?download=true.

8. Pylypovych, O., \& Kovslchuk, I. (2017). Geoecology of the Upper Dniester river-basin system. Lviv, Kyiv: LNU of Ivan Franko (in Ukrainian).

9. Russell, S. J., \& Norvig, P. (2010). Artificial Intelligence: A Modern Approach (3rd ed.). New Jersey: Pearson Education: Upper Saddle River.

10. Reiter, R. (2001). Knowledge in Action: Logical Foundations for Specifying and Implementing Dynamical Systems. MIT Press.

11. McCarthy, J. (1963). Situations, actions, and causal laws. Memo 2: Stanford University Artificial Intelligence Project. Retrieved from http://www.dtic.mil/dtic/tr/fulltext/ u2/785031.pdf.

12. Stefanyshyn, D. V. (2013). A method of forecasting of indexes of dynamic system that evolves slowly, based on time series analysis. In 4th Int. Conf. on Inductive Modelling (pp. 221-224). Kyiv, Ukraine.

13. Stefanyshyn, D. V. (2017). Improving diagnostic models for forecasting the behavior of dams equipped with automated monitoring systems. Mathematical modeling in economy, (3-4), 50-61.

14. Kuhn, M., \& Johnson, K. (2013). Applied Predictive Modeling. New York: Springer Science+Business Media.

15. Geisser, S. (2016). Predictive Inference: An Introduction. New York: Chapman \& Hall. 16. Brockwell, P. J., \& Davis, R. A. (1991). Time series: Theory and methods (2nd ed.). Springer.

17. Hamilton, J. D. (1994). Time series analysis. Princeton, New Jersey: Princeton University Press.

18. Viessman, W. (Ed.). (1975). Introduction to hydrology (1st ed.). New York, London: Intext educational publishers.

19. Extreme Hydrological Events: New Concepts for Security (1st ed., Vol. IV: Earth and

Environmental Sciences, Nato Science Series). (2007). Retrieved from https://link.springer.com/book/10.1007/978-1-4020-5741-0

20. Koutsoyiannis, D. (2008). Probability and statistics for geophysical processes. Athens: National Technical University of Athens. Retrieved from https://www.itia.ntua.gr/en/docinfo/1322/.

21. Stefanyshyn, D. V. (2018). On the use of the type I Gumbel distribution to assess risks given floods. Mathematical modeling in economy, (1), 74-83.

22. Taleb, N. N. (2010). The Black Swan. The Impact of the Highly Improbable (2nd enlarged ed.). New York: Random House.

23. Kirshners, A., \& Borisov, A. A. (2012). Comparative Analysis of Short Time Series Processing Methods. Information Technology and Management Science, (15), 65-69.

24. Trofymchuk, O., Kaliukh, I., \& Klimenkov, O. (2018). TXT-tool 2.380-1.1: Monitoring and Early Warning System of the Building Constructions of the Livadia Palace, Ukraine. In Landslide Dynamics: ISDR-ICL Landslide Interactive Teaching Tools (pp. 491-508).

The article was received 22.01.2019 and was accepted after revision 06.02.2019

\section{Д.В. Стефанишин, В.М. Корбутяк, Ю.Д. Стефанишина-Гаврилюк СИТУАЦЙНО-ПРОГНОСТИЧНЕ МОДЕЛЮВАННЯ НЕБЕЗПЕКИ ПОВЕНЕЙ В ДОЛИНІ РІЧКИ ДНІСТЕР БІЛЯ МІСТА ГАЛИЧ}

Анотація. Представлено метод ситуаційно-прогностичного моделювання небезпеки повеней в долині річки Дністер біля міста Галич на підставі даних гідрологічних спостережень, отриманих на гідрологічному посту «Галич». Виявлено деякі характерні особливості в поведінці рівняння зв'язку між рівнями і витратами 
води для водомірного поста «Галич», зокрема закономірності, що сприяють надійному прогнозуванню небезпеки повеней за допомогою статистичних даних, i неоднозначності, що ускладнюють подібне прогнозування. Показана можливість ефективного прогнозування небезпеки повеней в розглянутому районі за поточними даними гідрологічних спостережень для мінімізації можливих збитків і втрат.

Ключові слова: неоднозначність; дані; річка Дністер; небезпека повеней; гідрологічні спостереження; ситуаційна модель; ситуаційно-прогностичне моделювання

\section{Стефанишин Дмитро Володимирович}

доктор технічних наук, провідний науковий співробітник Інституту телекомунікацій i глобального інформаційного простору НАН України, професор кафедри гідротехнічного будівництва та гідравліки Національного університету водного господарства та природокористування (НУВГП)

Адреса робоча: 33028 Україна, м. Рівне, вул. Соборна, 11

e-mail:d.v.stefanyshyn@nuwm.edu.ua

ORCID ID: 0000-0002-7620-1613

\section{Корбутяк Василь Михайлович}

кандидат технічних наук, доцент кафедри землеустрою, кадастру, моніторингу земель та геоінформатики Національного університету водного господарства та природокористування (НУВГП)

Адреса робоча: 33028 Україна, м. Рівне, вул. Соборна, 11

ORCID ID: 0000-0002-8273-2306

\section{Стефанишина-Гаврилюк Юлія Дмитрівна}

магістр з екології та охорони навколишнього середовища, менеджер ПП «АМ Лінгвіста» Адреса робоча: 33028 Україна, м. Рівне, вулиця Княгині Ольги, 5, офіс 314

ORCID ID: 0000-0002-4121-5484 